\title{
Rainfall Variations Due to Twin Typhoons over Northwest Pacific Ocean
}

\author{
Shengyan Yu, M. V. Subrahmanyam* \\ School of Marine Science and Technology, Zhejiang Ocean University, Zhoushan, China \\ Email: ${ }^{\star m}$ vsm.au@gmail.com
}

How to cite this paper: $\mathrm{Yu}, \mathrm{S}$.Y. and $\mathrm{Su}-$ brahmanyam, M.V. (2017) Rainfall Variations Due to Twin Typhoons over Northwest Pacific Ocean. Open Access Library Journal, 4: e3638. https://doi.org/10.4236/oalib.1103638

Received: April 26, 2017

Accepted: May 16, 2017

Published: May 19, 2017

Copyright $\odot 2017$ by authors and Open Access Library Inc.

This work is licensed under the Creative Commons Attribution International License (CC BY 4.0).

http://creativecommons.org/licenses/by/4.0/ (c) (i) Open Access

\begin{abstract}
This paper focuses on the investigation of the rainfall variations due to twin typhoons Saola and Damrey occurred in 2012 over Northwest Pacific Ocean (NPO). Genesis and landfall of the two typhoons are on the same day, however the track and rainfall area are different. We have chosen the Global Precipitation Climatology Project (GPCP) and Tropical Rainfall Measuring Mission (TRMM) data for this analysis. The results are illustrating as follows: typhoon Saola produced higher rainfall than typhoon Damery. The rainfall pattern of typhoon Saola having sufficient affect typhoon Damrey rainfall over the ocean, however after landfall produced rainfall over the land. Comparison of two rainfall data sets revealing that TRMM data is better for identifying heavy rainfall due to typhoon.
\end{abstract}

\section{Subject Areas}

Atmospheric Sciences, Oceanology

\section{Keywords}

Twin Typhoons, Rainfall, GPCP, TRMM

\section{Introduction}

Typhoons interact with both the upper ocean and the atmosphere. Typhoons are gaining their energy from the warmer ocean surface and also lose its temperature that can continue for long after the typhoon has passed. Typhoons obtaining their energy from the warmer ocean and tend to be more intensify if the heat and moisture fluxes from the ocean are greater (Emanuel 1999 [1]). Typhoon is characterized by intense cyclonic winds, well organized deep convection, and spiral rain bands. Several typhoons that strike East Asia every year suffer severe damages. Torrential rainfall associated with typhoon landfall is one of the most 
devastating natural disasters in the coastal regions of China, which include huge losses in property and human lives (Zhang et al., 2009 [2]). Several observational studies suggest an increasing trend in typhoon rainfall and intensity in various regions of East Asian countries (Kim et al., 2006 [3]; Lau et al., 2008 [4]; Lau and Zhou 2012 [5]). Knutson et al., 2010 [6] suggest that TC intensity and precipitation could increase with global warming, frequency may decrease and different basins have considerable variability. The heavy rainfall associated with heavy rainfall, enhanced water vapor capacity caused a positive interaction between water vapor supply and typhoon (Hsu et al., 2011 [7]; Chang et al., 2012 [8]), and however it is the subject of intense debate. Rainfall magnitude and distribution induced by typhoon is often multiscale in nature and affected by many factors such as storm size, track, translation speed, etc. Rainfall associated with a typhoon can become asymmetric after landfall. The asymmetry in rainfall can be attributed to the impact of the typhoon moving speed (Shapiro 1983 [9]; Bender 1997 [10]; Frank and Ritchie 1999 [11]; Lonfat et al., 2004 [12]). The regions that suffer most are largely determined by the distribution of rainfall in typhoons. The spatial distribution of rainfall in a landfalling TC is of particular interest to meteorologists because of its relevance to the rainfall forecasts. Typhoon landfall precipitation forecast is completed due to the coastal and inland topography and land surface and boundary layer conditions (Lin et al., 2001b [13]; Li et al., 2003 [14]).

Previous studies explained the precipitation spatial distribution is complex and different for each of the typhoons (e.g., Miller 1958 [15]; Marks 1985 [16]; Burpee and Black 1989 [17]). Convection process will increase with the warmer temperature and heavy rainfall can influence sea surface temperature through the rain sensible heat flux. The stabilizing effect of rain can weaken the cold wake but that the associated sensible flux only marginally influences typhoon induced cooling (Jacob and Koblinsky 2007 [18]). Rainfall intensity increases with its typhoon intensity (Prat and Nelson 2012 [19]). Typhoons have stronger convective rain in the inner core as well as stronger stratiform rain in the rain band than cloud clusters (Chie and Yukari 2008 [20]). The heaviest precipitation generally took place in the front of a typhoon and the asymmetry in typhoon precipitation varies with typhoon intensity (Lonfat et al., 2004 [12]), more asymmetric precipitation distribution occurs for weaker the typhoon. In some cases, strongest precipitation occurred in the rear of a typhoon (Blackwell 2000 [21]). Typhoon translation can have significant effects on the asymmetric distribution in typhoon rainfall (Chen et al., 2006 [22]). Heavier precipitation mostly occurred far away from the center, thus bearing the common feature of weak typhoon. Willoughby et al., 1984 [23] found that, near surface strong wind speed is highly correlated with the spatial distribution of precipitation in "typhoon Bilis (2006)". Rainfall distribution in the left side of the typhoon track is higher than in the right side of the track (Subrahmanyam 2015 [24]). In the present paper, we are verifying the rainfall distribution due to twin typhoons occurred over the northwest Pacific Ocean (NPO) using different rainfall products 
available. It is found that rainfall distribution of one typhoon influences another typhoon, discussed in further sections.

\section{Data and Methodology}

In the NPO, twin typhoons occur rarely at the same time, however occurrence of continuous typhoons is obvious. The information of typhoons for this study, such as the typhoon track, intensity and central pressure data can be obtained from JTWC (Chu et al., 2002 [25]). The rainfall pattern due to twin typhoons was studied by using GPCP and TRMM rainfall data. The daily GPCP rainfall data was used for this study with the resolution of $1^{\circ} \times 1^{\circ}$. The World Climate Research Program (WRCP) and GEWEX, provides community global precipitation products with satellite and gauge information at the daily (Huffman et al., 2001 [26]), pentad (Xie et al., 2003 [27]), and monthly (Adler et al., 2003a [28]) time scales. This data is indicative of daily rainfall spatially and temporally. GPCP data can used to analyze rainfall pattern due to twin typhoons. Another rainfall data used for this study was TRMM daily rainfall data which is a joint mission between NASA and the Japan Aerospace Exploration (JAXA) Agency to study rainfall for weather and climate research. TRMM carried 5 instruments: a 3-sensor rainfall suite (PR, TMI, VIRS) and 2 related instruments (LIS and CERES). TRMM-Multi-satellite Precipitation Analysis (TMPA) 3B42 precipitation product version 7 (Huffman et al., 2007 [29]) has spatial resolution of $0.25^{\circ}$ grid and covering the globe from $50^{\circ} \mathrm{S}$ to $50^{\circ} \mathrm{N}$. TRMM $3 \mathrm{~B} 42$ has been frequently used for TC rainfall analysis regionally and globally (Shepherd et al., 2007 [30]; Jiang et al., 2012 [31]; Prat et al., 2012 [19]). GPCP and TRMM rainfall data have been used to analyse the variations in rainfall over the study area which are plotted during two ttyphoonspassage. In this case, we linearly interpolated the GPCP and TRMM data over 3 regions on each typhoon track.

The aim of this work is to find out the rainfall variations during the typhoons and influence in rainfall distribution changes due to two typhoons compared with different data sets. The data for this study GPCP and TRMM data have been chosen over the study area $\left(10^{\circ} \mathrm{N}-40^{\circ} \mathrm{N} ; 110^{\circ} \mathrm{E}-150^{\circ} \mathrm{E}\right)$. We have chosen 3 regions over each typhoon track represent typical areas considered for rainfall variation to compare the variations between two data sets.

\section{General Descriptions of Typhoons Saola and Damrey}

The area of study is within a range of $10^{\circ} \mathrm{N}-40^{\circ} \mathrm{N}$ and $110^{\circ} \mathrm{E}-150^{\circ} \mathrm{E}$ (Figure 1 ). The tracks of the two typhoons were passing the East China Sea (ECS), one is called Saola and the other is called Damery. The time period of these two typhoons was from 26 July to 11 Aug, 2012. The activity of typhoon Damery on the northeast of Saola brought much uncertainty to the operational forecast of Saola. Figure 1 depicts the tracks of two typhoons passing through the NPO, pressure as an indicator. Saola and Damrey are two typhoons formed on day 27 July 2012 over the NPO and also landed on day 3 August 2012 (same day) at different locations of east China coast. On 27 July 2012, Saola is first typhoon 


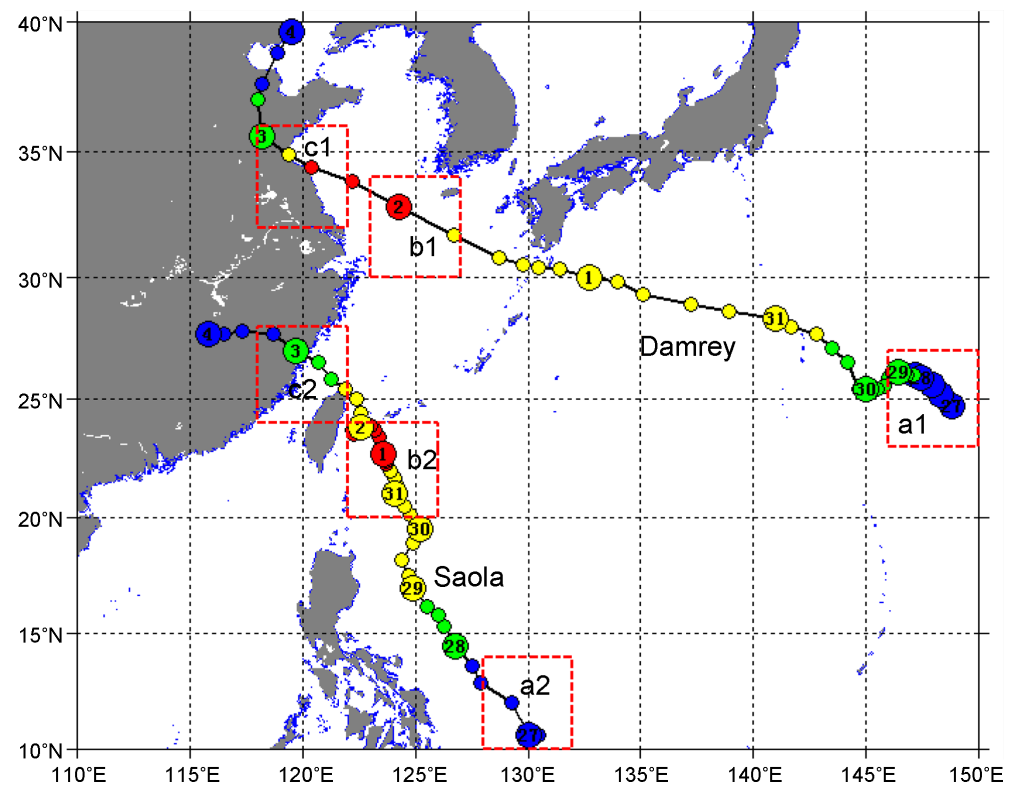

Figure 1. Typhoon tracks of "Saola" and "Damrey". The colors within the circles indicating central pressure of the typhoon at each position from JTWC. a1, b1, c1, a2, b2, c2 are six regions. The domain of a1 is $23^{\circ} \mathrm{N}-27^{\circ} \mathrm{N} ; 146^{\circ} \mathrm{E}-150^{\circ} \mathrm{E}$; The domain of a2 is $10^{\circ} \mathrm{N}-14^{\circ} \mathrm{N} ; 128^{\circ} \mathrm{E}-132^{\circ} \mathrm{E}$; The domain of b1 is $30^{\circ} \mathrm{N}-34^{\circ} \mathrm{N} ; 123^{\circ} \mathrm{E}-127^{\circ} \mathrm{E}$; The domain of b2 is $20^{\circ} \mathrm{N}-24^{\circ} \mathrm{N} ; 122^{\circ} \mathrm{E}-126^{\circ} \mathrm{E}$; The domain of $\mathrm{c} 1$ is $32^{\circ} \mathrm{N}-36^{\circ} \mathrm{N} ; 118^{\circ} \mathrm{E}-$ $122^{\circ} \mathrm{E}$; The domain of $\mathrm{c} 2$ is $24^{\circ} \mathrm{N}-28^{\circ} \mathrm{N} ; 118^{\circ} \mathrm{E}-122^{\circ} \mathrm{E}$.

which formed as low pressure systems with an initial strength of $1004 \mathrm{hPa}$ at $10.6^{\circ} \mathrm{N}, 130^{\circ} \mathrm{E}$ and the second one is Damrey formed over the NPO with an initial strength of $1008 \mathrm{hPa}$ at $24.7^{\circ} \mathrm{N}, 148.8^{\circ}$ E. Both Saola and Damrey landed on the same day (3 August 2012) at different locations such as Fujian and Zhejiang provinces which happen very rarely. On 27 July 2012 typhoon Damrey and Saola genesis, received energy from the sea, produced heavy precipitation over the sea and cooled the sea surface. On 27 July, typhoon Saola moved slowly for a long time after genesis and moving north and west with complex moving processes. From 27 July to 1 August, the surface wind speeds gradually increased and reached the maximum $70 \mathrm{~m} / \mathrm{s}$ leading to strong typhoon Saola at the location of $122.7^{\circ} \mathrm{E}, 24.1^{\circ} \mathrm{N}$ with the central pressure of $960 \mathrm{hPa}$. Typhoon Damrey with small size but moved faster than Saola. On 1 Aug, the intensity of typhoon Damrey enhanced from strong tropical storm to typhoon. On 2 Aug, the maximum wind speed near its core was $70 \mathrm{~m} / \mathrm{s}$ at the location $122.8^{\circ} \mathrm{E} ; 33.5^{\circ} \mathrm{N}$ with the central pressure of $965 \mathrm{hPa}$. After the faster movement of Darmery, the distance between Saola and Damery was less than 10 latitude distance for 1.5 days when the mutual rotations of binary typhoons were not obvious.

\section{Results}

\subsection{Rainfall Variations Using GPCP Data and TRMM Data}

The precipitation variations due to typhoon over the oceans have been shown described in earlier studies, mainly controlled by various factors such as evaporation latent heat, internal power and external environmental flow field (Zehr 
1992 [32]; Emanuel 1986 [33]; Merrill 1988 [34]; Gray and Jacobson 1977 [35]; Steranka et al. 1984 [36]). Figure 2 shows the daily rainfall variations for the period from July 27 to August 4 using GPCP rainfall data and daily variations of TRMM rainfall data are illustrated in Figure 3. It can be seen from Figure 1 that two cyclones were generated in the northwestern Pacific Ocean at the same time. The generation positions of typhoon Saola and Damrey were at $10.6^{\circ} \mathrm{N}, 130^{\circ} \mathrm{E}$ and $24.7^{\circ} \mathrm{N}, 148.8^{\circ} \mathrm{E}$ respectively. Both typhoons brought rainfall at generated places (Figure 2 and Figure 3 ). When considering the GPCP data, the rainfall range of the Saola induced was higher than that of the Damrey, and typhoon Saola rainfall distribution mainly on the right side of the typhoon track. The cumulative rainfall due to Damrey was lower than that of Saola because the latent heat of the typhoon Saola was higher. Damrey passing over the latitude above $20^{\circ} \mathrm{N}$, the sea surface temperature is lower than that of the lower latitudes. In the high latitude region, the temperature gradient is large and if the mechanical disturbance of the typhoon happened, it is obvious that sea surface temperature cooling trend occurred. In the lower latitude regain the temperature gradient is weak, almost becoming an isothermal water layer. When the typhoon passed, the sea surface temperature cooling phenomenon is also not obvious. Compared to GPCP rainfall, the TRMM rainfall was indicating higher cumulative rainfall. The spatial range of GPCP data was higher than TRMM. Rainfall of
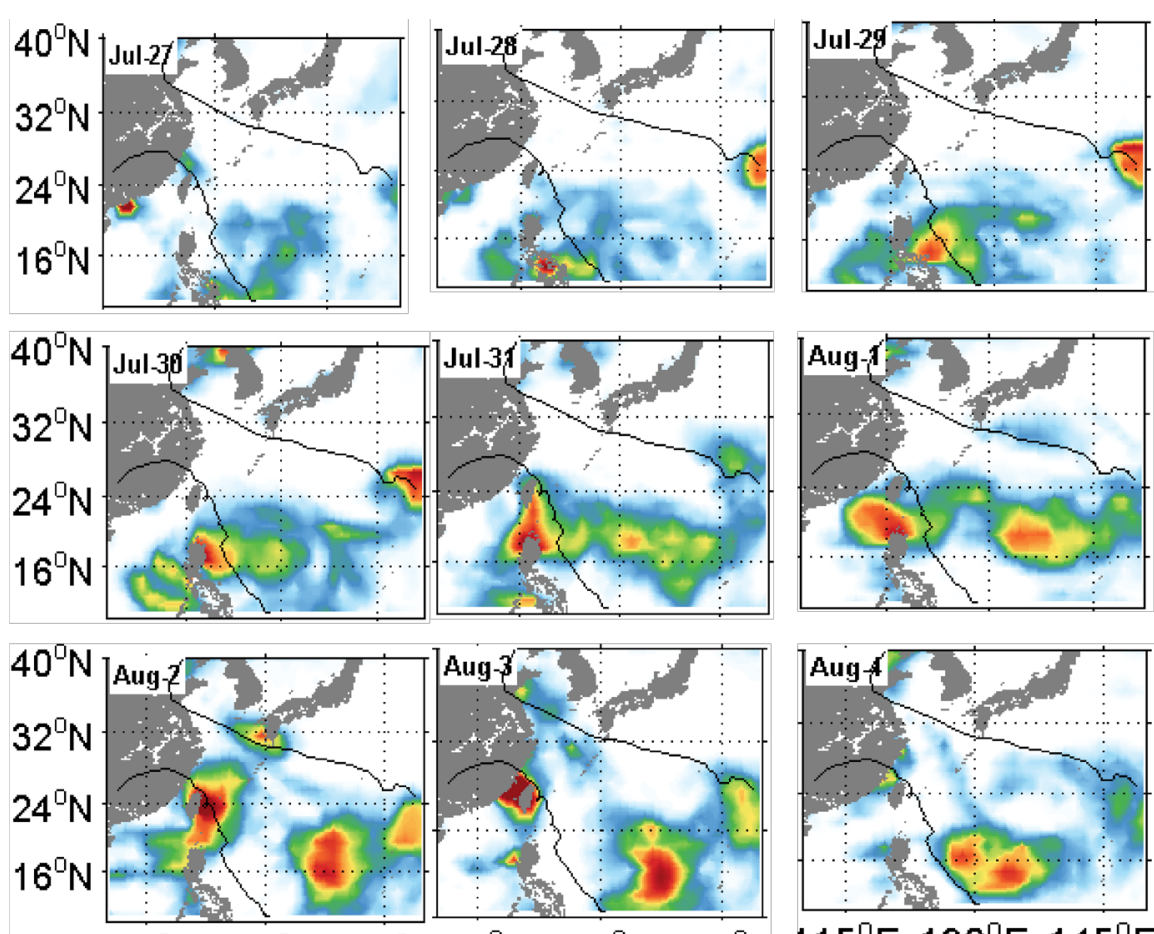

$115^{\circ} \mathrm{E} 130^{\circ} \mathrm{E} 145^{\circ} \mathrm{E} 115^{\circ} \mathrm{E} 130^{\circ} \mathrm{E} 145^{\circ} \mathrm{E} 115^{\circ} \mathrm{E} 130^{\circ} \mathrm{E} 145^{\circ} \mathrm{E}$

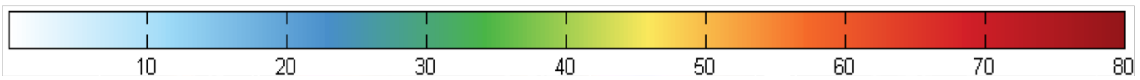

Figure 2. Variation of GPCP precipitation (mm/day) (color shading) on 27 July to $4 \mathrm{Au}$ gust 2012 during the passage of two typhoons Saola and Damrey. The two lines indicate the central pressure of the typhoon at each position along the best track. 

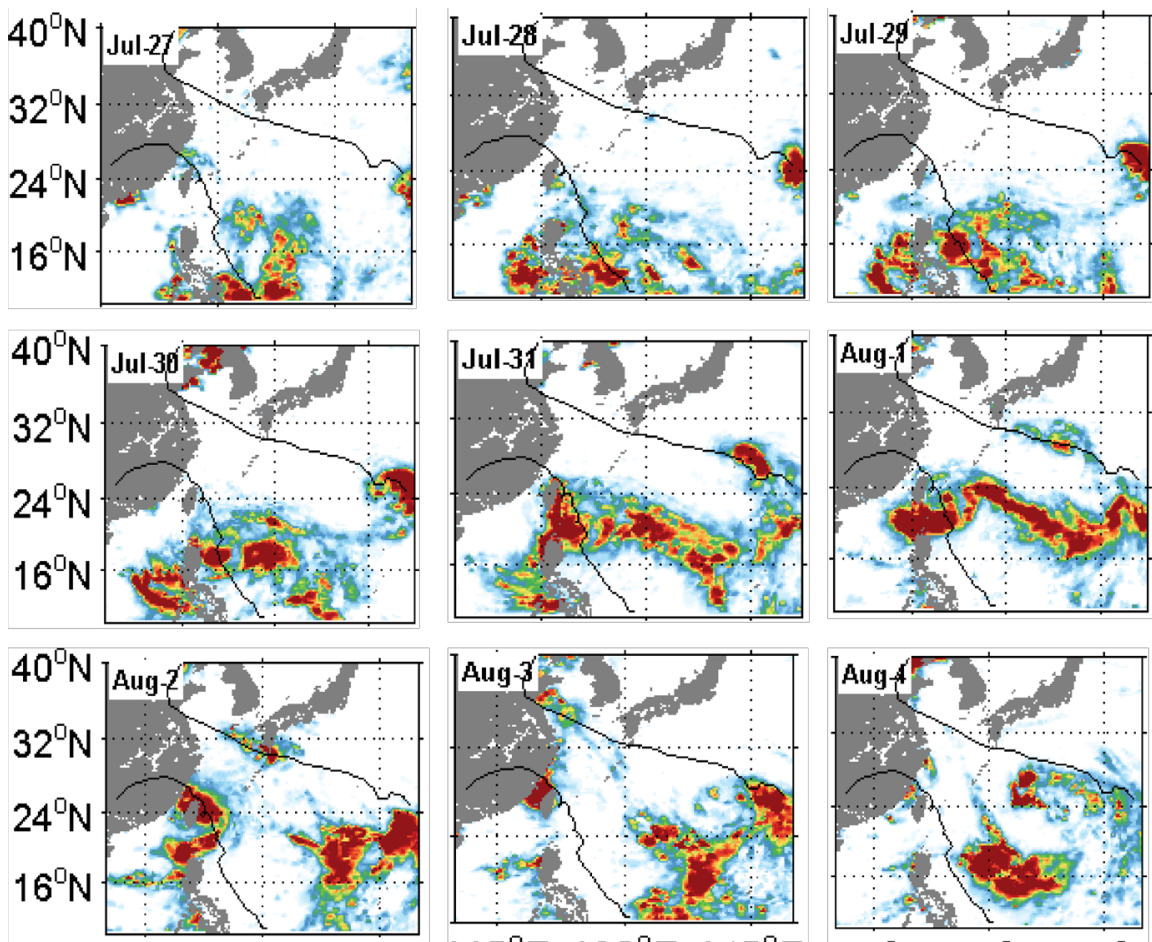

$115^{\circ} \mathrm{E} 130^{\circ} \mathrm{E} 145^{\circ} \mathrm{E}$

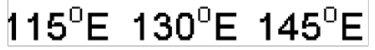

$115^{\circ} \mathrm{E} 130^{\circ} \mathrm{E} 145^{\circ} \mathrm{E}$

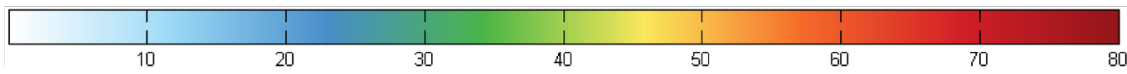

Figure 3. Variation of TRMM precipitation (mm/day) (color shading) on 27 July to 4 August 2012 during the passage of two typhoons Saola and Damrey. The two lines indicate the central pressure of the typhoon at each position along the best track.

$70 \mathrm{~mm} / \mathrm{d}$ occurred on 28th July over the Philippine Island which was mainly caused by typhoon Saola (Figure 2). The terrain on the island and the warm air produce high intensity of rainfall on the island of the Philippines. Heavy rainfall of $50 \mathrm{~mm}$ was also observed in the vicinity of Damrey. Higher than $100 \mathrm{~mm}$ rainfall induced by Damrey was observed on the 28th July (Figure 3 ). The difference of maximum rainfall between GPCP and TRMM was $50 \mathrm{~mm}$. TRMM data is better to reflect the amount of rainfall. On 29th July, with the movement of Saola, the maximum rainfall occurred in the left side of Saola which was moving to the northeast (Figure 2). Furthermore, the spatial distribution of heavy rainfall was quite concentrated near to track as revealed in Figure 2. Compared to 28th July, no obvious difference of movement occurred on 29th. The patch of higher rainfall was scattered in Figure 3 on 29th July. Before 30th July, the moving speed of Saola was higher than Damrey. After 30th July, the moving speed of Damrey accelerated. The patch of rainfall was almost the similar on 30th July as indicated in Figure 2 and Figure 3; however TRMM rainfall was higher than GPCP rainfall. On 31th July, the daily rainfall near Damrey appeared a reduction and almost became $0 \mathrm{~mm}$. The rainfall mainly distributed in the right side of the Damrey's track, at the generation area of Damrey, there was a patch of significant SST drop of $3^{\circ} \mathrm{C}$ around the typhoon center happened on the right side of the Damrey. The rainfall but mainly distributed in the right side 
of the Damrey track was different from the previous rainfall area. There were obvious two rainfall areas with higher intensity caused by Saola, one distributed in the Luzon Strait, Showing the shape of the triangle. At that time, there was no obvious sea temperature cooling phenomenon. The sea surface temperature and the latent heat of evaporation were relatively high, so it will contribute for rainfall. The other area was at $125^{\circ} \mathrm{E}-145^{\circ} \mathrm{E}, 16^{\circ} \mathrm{N}-24^{\circ} \mathrm{N}$, which was contributing for a large-scale rainfall phenomenon because the latent heat over the sea was higher than that of in the Luzon Strait. On 31st July, amount of TRMM rainfall was higher than GPCP. The amount of rainfall brought by Damrey became to increase and reached about $20 \mathrm{~mm}$ on 1st August, and spatial distribution mainly confined to the right side of Damrey. Rainfall area caused by the Saola appeared in two circles; one distributed in the right side of Saola, the other was on the opposite side on 31th. On 1st August, one can clearly found that the typhoon-induced rainfall area in Figure 3 was smaller than Figure 2. The shape of rainfall distributed was strip-like in Figure 3, but the strength was higher than that in Figure 2. On 2nd August, after Typhoon Saola occurred cyclonic rotation, it landed at Taiwan Island. Substantial rainfall occurred over Taiwan Island and on the eastern side of Taiwan Island, the maximum rainfall reached to 80 $\mathrm{mm} / \mathrm{d}$. Figure 3 illustrated a small range of rainfall on the right side of the typhoon Saola's track, however large rainfall occurred on the left side of the Saola. In Figure 2, when typhoon Saola passed through Taiwan Island, clearly indicating that, typhoon Saola induced rainfall area was well-distributed on both sides of the typhoon's path. On 3rd August, typhoon Saola and Damrey landed on the same day in Chinese mainland. After Saola landed, high-intensity rainfall happened over the Taiwan Strait where the strongest rainfall during the period of typhoon's passage was observed. At the same time, a small amount of rainfall happened in the Yellow Sea. There was also a rainfall of $40 \mathrm{~mm} /$ day in the area where the tropical cyclone was formed. Figure 3 demonstrated that the distribution of rainfall in the Taiwan Strait was similar to that in Figure 2. The amount of TRMM rainfall was smaller than GPCP in coastal area and in other areas was larger than that of GPCP. On 4th August, when the two typhoons landed, the inland areas of rainfall happened, but in the Taiwan Strait, the rainfall reduced as indicated in Figure 2. Spatial distribution increased in the right side of the Typhoon Saola $\left(125^{\circ} \mathrm{E}-140^{\circ} \mathrm{E}, 10^{\circ} \mathrm{N}-18^{\circ} \mathrm{N}\right)$. On 4th August, in Figure 3, the amount of rainfall on the left side of the Damrey track was larger than that in Figure 2.

\subsection{Comparisons between TRMM and GPCP}

Figure 4 illustrate the daily rainfall variation for the three different regions randomly selected using GPCP and TRMM data respectively. Figure 4(a1) and Figure 4(a2) represent two typhoon-generating regions, located at $23^{\circ} \mathrm{N}-27^{\circ} \mathrm{N}$, $146^{\circ} \mathrm{E}-150^{\circ} \mathrm{E} ; 10^{\circ} \mathrm{N}-14^{\circ} \mathrm{N} ; 128^{\circ} \mathrm{E}-132^{\circ} \mathrm{E}$. Figure $4(\mathrm{~b} 1)$ and Figure $4(\mathrm{~b} 2)$ in dicates the typhoon center with high intensity, located at $30^{\circ} \mathrm{N}-34^{\circ} \mathrm{N}, 123^{\circ} \mathrm{E}$ $127^{\circ} \mathrm{E} ; 20^{\circ} \mathrm{N}-24^{\circ} \mathrm{N} ; 122^{\circ} \mathrm{E}-126^{\circ} \mathrm{E}$. Figure $4(\mathrm{c} 1)$ and Figure $4(\mathrm{c} 2)$ represent the 

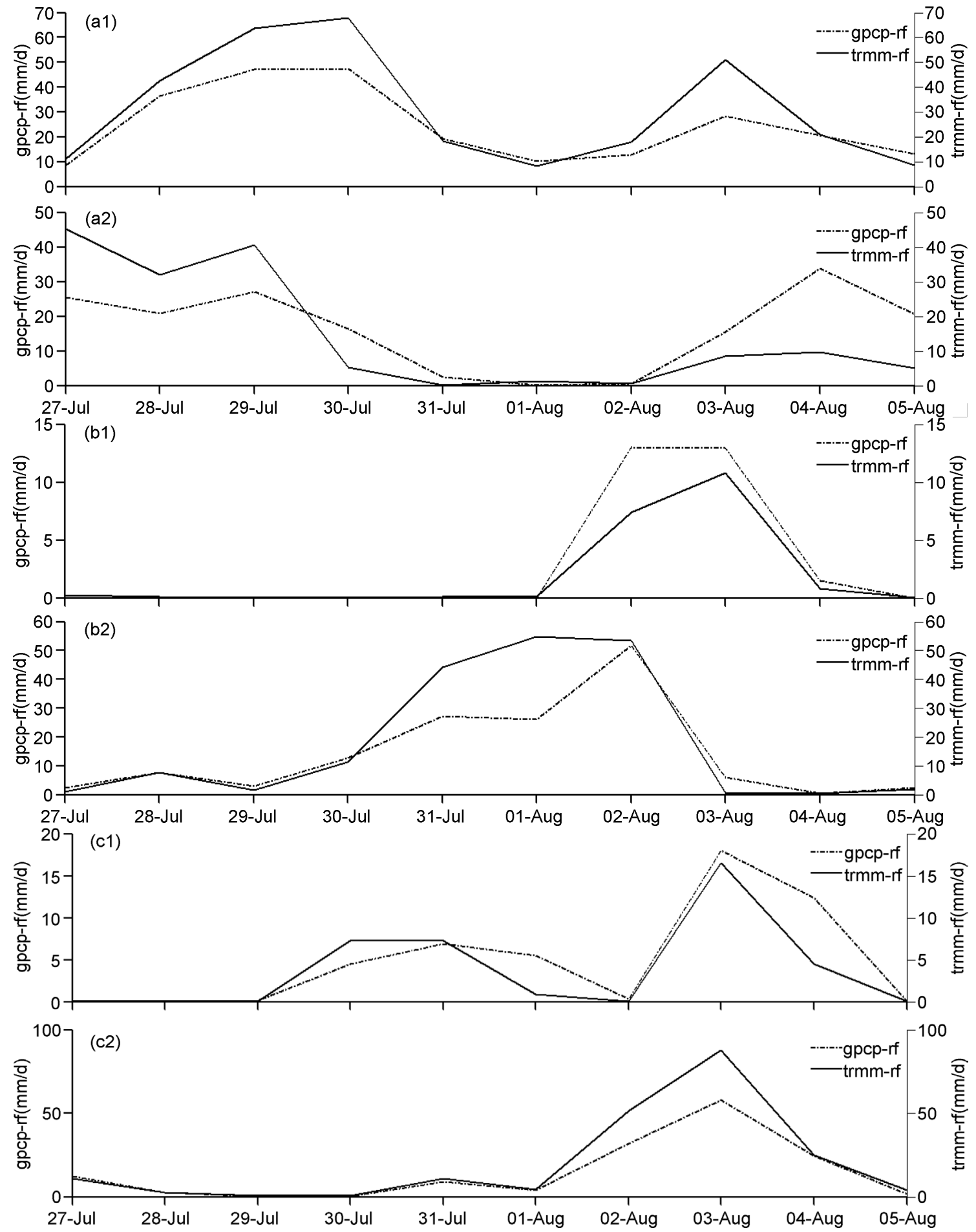

Figure 4. Variation of rainfall on 27 July to 5 August 2012, dashed line indicates GPCP and solid line indicates TRMM. The domain of (a1), (a2), (b1), (b2), (c1), (c2) is same as shown in Figure 1.

area along the coast, the position are $32^{\circ} \mathrm{N}-36^{\circ} \mathrm{N}, 118^{\circ} \mathrm{E}-122^{\circ} \mathrm{E} ; 24^{\circ} \mathrm{N}-28^{\circ} \mathrm{N}$, $118^{\circ} \mathrm{E}-122^{\circ} \mathrm{E}$. It was clear that the rainfall obtained from TRMM was higher than GPCP data in Figure 4(a1), and the difference of $25 \mathrm{~mm}$ rainfall between GPCP and TRMM data on August 3 which was the maximum. In the Figure 4(a2), from July 31 to Aug 2, the two data received almost similar amount of 
rainfall, TRMM rainfall data was higher than GPCP on July $27,28,29$, but on August 2 TRMM rainfall was lower than GPCP. On August 4, the maximum difference was $25 \mathrm{~mm}$ in the higher rainfall region. The area of (b1) was higher intensity area over the typhoon and no rainfall observed before August 1 because the typhoon has not reached the sea area. When the typhoon reached the maximum intensity, Figure 4(b1) illustrating GPCP rainfall was higher than TRMM. It is clearly visible that GPCP data is reliable than TRMM when rainfall less than $15 \mathrm{~mm}$. Over the typhoon Saola passed area, TRMM data is superior to GPCP at high intensity rainfall indicated in Figure 4(b2). The Figure 4(b1) and Figure 4 (b2) showing there was no significant difference in the rainfall between TRMM and GPCP before and after the typhoons passage. But during typhoons passage, GPCP rainfall was higher than TRMM when the rainfall was lower than $15 \mathrm{~mm}$ (Figure 4(b1)). In contrast, there were three days of rainfall above $15 \mathrm{~mm}$, respectively on 31 July, 1and 2 Aug, TRMM rainfall was reversed, exceeding GPCP with the typhoon approaching (Figure 4(b2)). Figure 4(c1) and Figure 4(c2) are the rainfall variations over landfall area. In Figure 4(c1), rainfall from $\mathrm{Au}-$ gust 1 to 5 was less than $20 \mathrm{~mm}$, GPCP rainfall exceeded TRMM. However, TRMM rainfall was higher than GPCP when heavy rainfall occurred (Figure 4(c2)). In summary, when the rainfall is small, GPCP data is better than TRMM; when the rainfall is large, TRMM data can reflect the real rainfall.

\section{Discussion}

The rainfall production by TCs is also influenced by environmental parameters such as sea surface moisture flux, vertical wind shear, storm intensity, and topography. In this present study, we cover the period of the time between July 27 and Aug 4, 2012. The GPCP data and TRMM data are used to estimate the magnitude of the rainfall, and GPCP and TRMM rainfall data compared in the present study.

In this paper, the first question involves that one heavy rainfall was located in the region of $135^{\circ} \mathrm{E}-140^{\circ} \mathrm{E}, 15^{\circ} \mathrm{N}-20^{\circ} \mathrm{N}$. Water vapor and latent heat are the prerequisites for precipitation. The water vapor transport and latent heat in the atmosphere play an important role in the occurrence and maintenance of tropical cyclones and the relationship with tropical cyclone precipitation is inseparable. When typhoon is passing through study area, the latent heat release plays an important role that warms the atmosphere, causing a depression of the surface pressure, is the reason that leads to a larger pressure difference in the zonal direction. Amplification of water vapor flux in to foothills due to pressure gradient which guide and enhancing the water vapor flux divergence, increases typhoon rainfall (Huang 2014 [37]). The second problem relates to the other high rainfall parts such as at Taiwan Island and Philippine Island, many previous studies have shown that it is possible to cause airflow to flow upside due to terrain. At north of Taiwan Island, there are Mountains which is rich of water vapor. Strong winds, high humidity and typhoon peripheral airflow help to lead to orographic lifting to produce extremely heavy precipitation (Huang 2014 [37]; Yunying et 
al., 2007 [38]). When Saola passed through north off Taiwan coast, it played a counter-clockwise rotate possibly due to the impact of terrain in Taiwan. However, the activity of typhoon Damery on the northeast of Saola brought much uncertainty to the operational forecast of Saola. The close existence of Damery has changed the basic steering flow, the water vapor transportation, the intensity variation and the structural feature of Saola. As a result, both the moving direction and velocity of Saola have changed in later period and Saola showed an asymmetric structure and abnormal rainfall distributions during landfall at $\mathrm{Fu}$ jian province. Its precipitation characteristics were significantly different from the similar typhoons such as Haitang and Billis typhoons (Fan et al., 2014 [39]). After Typhoon Saola landed at Taiwan (Alpers W et al., 2007 [40]), the impact of special terrain led to the wind reduced and the moving speed decreased. The humid air encountered the large mountains; the mountain windward slope would force it to accelerate the rising and the condensation, so that the rainfall even became fiercer. Similarly, Damrey was close to the Japan so the Damrey induced rainfall mainly distributed in the right side of track, the Kyushu Island and the south of Kyushu Island (Huang 2014 [37]; Yunying et al., 2007 [38]).

Comparing these two data sets, TRMM data gives better estimations when the rainfall value is higher than $15 \mathrm{~mm}$, but GPCP data is more reliable when rainfall is less than $15 \mathrm{~mm}$. This is probably a consequence of the different spatial resolution and sensitivity of the sensors. The spatial resolution of the TRMM data is $0.25 \times 0.25$, and the spatial resolution of the GPCP is $1 \times 1$. GPCP rainfall showing lower than TRMM, this may be the reason GPCP data is the mean of all available satellite and rain gauage data. The bias of TRMM might be from uncertainties of radar attenuation corrections and microwave retrieval algorithms [41] (Huffman et al., 2010). However, the uncertainties of both GPCP and TRMM rainfall may be due to estimation of satellite-based rainfall due to algorithms and rain gauge measurements may subject to underestimate. However both TRMM and GPCP can be used for typhoon rainfall, even though there are subject to uncertainties over large surface wind environment induced by typhoons.

\section{Conclusion}

Based on the GPCP and TRMM rainfall data, the rainfall pattern induced by twin typhoons is analyzed. The role of Saola impact on rainfall in the vicinity of Damrey and the effect of the terrain were influencing for heavy rainfall. In addition, we compare with these two data sets in different regions. The rainfall occurred due to Saola was higher than Damrey, and typhoon Saola rainfall distribution mainly on the right side of the typhoon track. Rainfall of $70 \mathrm{~mm} / \mathrm{d}$ occurred on 28th July over the Philippine Island which was mainly caused by typhoon Saola. There are two particular regions depicting higher rainfall, one region was on $135^{\circ} \mathrm{E}-140^{\circ} \mathrm{E}, 15^{\circ} \mathrm{N}-20^{\circ} \mathrm{N}$ and the other was on the Taiwan Island also at Philippine Island. When comparing GPCP and TRMM rainfall data, TRMM data is better for heavy rainfall events. However, when the rainfall is lower than $15 \mathrm{~mm}$, GPCP data are showing better estimations. 


\section{Acknowledgements}

Authors express their gratitude to GPCP and TRMM for providing the rainfall data for research work. Authors are thankful to the anonymous reviewers for useful comments for revising the manuscript.

\section{References}

[1] Emanuel, K.A. (1999) Thermodynamic Control of Hurricane Intensity. Nature, 401, 665-669. https://doi.org/10.1038/44326

[2] Zhang, Q., Liu, Q. and Wu, L. (2009) Tropical Cyclone Damages in China 19832006. Bulletin of the American Meteorological Society, 90, 489-495. https://doi.org/10.1175/2008BAMS2631.1

[3] Kim, J.-H., Ho, C.-H., Lee, M.-H., Jeong, J.-H. and Chen, D. (2006) Large Increase in Heavy Rainfall Associated with Tropical Cyclone Landfalls in Korea after the Late 1970s. Geophysical Research Letters, 33, L18706.

https://doi.org/10.1029/2006gl027430

[4] Lau, W.K.-M. and Wu, H.-T. (2008) Have Tropical Cyclones Been Feeding More Extreme Rainfall? Journal of Geophysical Research, 113, D23113.

https://doi.org/10.1029/2008jd009963

[5] Lau, W.K.-M. and Zhou, Y.P. (2012) Observed Recent Trends in Tropical Cyclone Rainfall over the North Atlantic and the North Pacific. Journal of Geophysical Research, 117, D03104. https://doi.org/10.1029/2011jd016510

[6] Knutson, T.R., et al. (2010) Tropical Cyclones and Climate Change. Nature Geoscience, 3, 157-163. https://doi.org/10.1038/ngeo779

[7] Hsu, H.-H., et al. (2011) Science Report of Climate Change in Taiwan 2011. National Science Council, 362 p. (In Chinese)

[8] Chang, C.-P., Lei, Y., Sui, C.-H., Lin, X. and Ren, F. (2012) Tropical Cyclone and Extreme Rainfall Trends in East Asian Summer Monsoon Since Mid-20th Century. Geophysical Research Letters, 39, L18702. https://doi.org/10.1029/2012gl052945

[9] Shapiro, L.J. (1983) Asymmetric Boundary Layer Flow under a Translating Hurricane. Journal of the Atmospheric Sciences, 40, 1984-1998. https://doi.org/10.1175/1520-0469(1983)040<1984:TABLFU>2.0.CO;2

[10] Bender, M A. (1997) The Effect of Relative Flow on the Asymmetric Structure in the Interior of Hurricanes. Journal of the Atmospheric Sciences, 54, 703-724. https://doi.org/10.1175/1520-0469(1997)054<0703:TEORFO>2.0.CO;2

[11] Frank, W.M. and Ritchie, E.A. (1999) Effects of Environmental Flow upon Tropical Cyclone Structure. Monthly Weather Review, 127, 2044-2061.

https://doi.org/10.1175/1520-0493(1999)127<2044:EOEFUT>2.0.CO;2

[12] Lonfat, M., Marks Jr., F.D. and Chen, S.S. (2004) Precipitation Distribution in Tropical Cyclones Using the Tropical Rainfall Measuring Mission (TRMM) Microwave Imager: A Global Perspective. Monthly Weather Review, 132, 1645-1660. https://doi.org/10.1175/1520-0493(2004)132<1645:PDITCU>2.0.CO;2

[13] Lin, Y.Y., Liu, Y.Q. and Zhang, L.Q. (2001) An Analysis on the Impact of Severe Tropical Storm "Maria" on the Torrential Heavy Rain in Shaoguan. Guangdong Meteorology, 3, 5-7. http://gdqx.qikanc.com/

[14] Li, J., et al. (2003) Advancement in the Study of Typhoon Rainstorm. Journal of Tropical Meteorology, 19, 152-159. (In Chinese)

[15] Miller, B.I. (1958) Rainfall Rates in Florida Hurricanes. Monthly Weather Review, 86, 258-264. https://doi.org/10.1175/1520-0493(1958)086<0258:RRIFH >2.0.CO;2 
[16] Marks Jr., F.D. (1985) Evolution of the Structure of Precipitation in Hurricane Allen (1980). Monthly Weather Review, 113, 909-930. https://doi.org/10.1175/1520-0493(1985)113<0909:EOTSOP>2.0.CO;2

[17] Burpee, R.W. and Black, M.L. (1989) Temporal and Spatial Variations of Rainfall near the Centers of Two Tropical Cyclones. Monthly Weather Review, 117, 22042218. https://doi.org/10.1175/1520-0493(1989)117<2204:TASVOR >2.0.CO;2

[18] Jacob, S.D. and Koblinsky, C. (2007) Effects of Precipitation on the Upper-Ocean Response to a Hurricane. Monthly Weather Review, 135, 2207-2225. https://doi.org/10.1175/MWR3366.1

[19] Prat, O.P. and Nelson, B.R. (2012) Precipitation Contribution of Tropical Cyclones in the Southeastern United States from 1998 to 2009 Using TRMM Satellite Data. Journal of Climate, 26, 1047-1062. https://doi.org/10.1175/JCLI-D-11-00736.1

[20] Yokoyama, C. and Takayabu, Y.N. (2008) A Statistical Study on Rain Characteristics of Tropical Cyclones Using TRMM Satellite Data. Monthly Weather Review, 136, 3848-3862. https://doi.org/10.1175/2008MWR2408.1

[21] Blackwell, K.G. (2000) The Evolution of Hurricane Danny (1997) at Landfall: Doppler Observed Eyewall Replacement, Vortex Contraction/Intensification, and Lowlevel Wind Maxima. Monthly Weather Review, 128, 4002-4016. https://doi.org/10.1175/1520-0493(2000)129<4002:TEOHDA>2.0.CO;2

[22] Chen, S.S., Knaff, J.A. and Marks Jr., F.D. (2006) Effects of Vertical Wind Shear and Storm Motion on Tropical Cyclone Rainfall Asymmetries Deduced from TRMM. Monthly Weather Review, 134, 3190-3208. https://doi.org/10.1175/MWR3245.1

[23] Willoughby, H.E., Marks Jr., F.D. and Feinberg, R.J. (1984) Stationary and Moving Convective Bands in Hurricanes. Journal of the Atmospheric Sciences, 41, 31893211. https://doi.org/10.1175/1520-0469(1984)041<3189:SAMCBI >2.0.CO;2

[24] Subrahmanyam, M.V. (2015) Impact of Typhoon on the North-West Pacific Sea Surface Temperature: A Case Study of Typhoon Kaemi (2006). Natural Hazards, 78, 569-582. https://doi.org/10.1007/s11069-015-1733-7

[25] Chu, J.H., Sampson, C.R., Levine, A.S. and Fukada, E. (2002) The Joint Typhoon Warning Center Tropical Cyclone Best-Tracks, 1945-2000. Rep. NRL/MR/7540-0216, Joint Typhoon Warning Center, Hawaii. http://www.usno.navy.mil/NOOC/nmfc-ph/RSS/jtwc/best_tracks/TC_bt_report.html

[26] Huffman, G.J., Adler, R.F., Morrissey, M., Bolvin, D.T., Curtis, S., Joyce, R., McGavock, B. and Susskind, J. (2001) Global Precipitation at One-Degree Daily Resolution from Multi Satellite Observations. Journal of Hydrometeorology, 2, 36-50. https://doi.org/10.1175/1525-7541(2001)002<0036:GPAODD>2.0.CO;2

[27] Xie, J., Janowiak, E., Arkin, P.A., Adler, R., Gruber, A., Ferraro, R., Huffman, G.J. and Curtis, S. (2003) GPCP Pentad Precipitation Analyses: An Experimental Data Set Based on Gauge Observations and Satellite Estimates. Journal of Climate, 16, 2197-2214. https://doi.org/10.1175/2769.1

[28] Adler, R.F., et al. (2003) The Version-2 Global Precipitation Climatology Project (GPCP) Monthly Precipitation Analysis (1979-Present). Journal of Hydrometeorology, 4, 1147-1167. https://doi.org/10.1175/1525-7541(2003)004<1147:TVGPCP>2.0.CO;2

[29] Huffman, G.J., Adler, R.F., Bolvin, D.T., Gu, G., Nelkin, E.J., Bowman, K.P., Stocker, E.F. and Wolff, D.B. (2007) The TRMM Multisatellite Precipitation Analysis (TMPA): Quasi-Global, Multiyear, Combined-Sensor Precipitation Estimates at Fine Scale. Journal of Hydrometeorology, 8, 38-55. https://doi.org/10.1175/jhm560.1

[30] Shepherd, J.M., Grundstein, A. and Mote, T.L. (2007) Quantifying the Contribution 
of Tropical Cyclones to Extreme Rainfall along the Coastal Southeastern United States. Geophysical Research Letters, 34, L23810.

https://doi.org/10.1029/2007gl031694

[31] Jiang, H., Ramirez, E.M. and Cecil, D.J. (2012) Convective and Rainfall Properties of Tropical Cyclone Inner Cores and Rainbands from 11 Years of TRMM Data. Monthly Weather Review, 141, 431-450. https://doi.org/10.1175/MWR-D-11-00360.1

[32] Zehr, R. (1992) Tropical Cyclogenesis in the Western North Pacific. NOAA Technical Report NESDIS, 16, $181 \mathrm{p}$.

[33] Emanuel, K.A. (1986) An Air-Sea Interaction Theory for Tropical Cyclones. Part I: Steady-State Maintenance. Journal of the Atmospheric Sciences, 43, 585-604. https://doi.org/10.1175/1520-0469(1986)043<0585:aasitf>2.0.co;2

[34] Merrill, R.T. (1988) Characteristic of the Upper-Tropospheric Environment Flow around Hurricanes. Journal of the Atmospheric Sciences, 45, 1665-1677. https://doi.org/10.1175/1520-0469(1988)045<1665:COTUTE >2.0.CO;2

[35] Gray, W.M. and Jacobso, R.W. (1977) Diurnal Variation of Deep Cumulus Convection. Monthly Weather Review, 105, 1171-1188.

[36] Steranka, J., Rodgers, E.B. and Gentry, R.C. (1984) The Diurnal Variation of Atlantic Ocean Tropical Cyclone Cloud Distribution Inferred from Geostationary Satellite Infrared Measurements. Monthly Weather Review, 112, 2338-2344. https://doi.org/10.1175/1520-0493(1984)112<2338:TDVOAO>2.0.CO;2

[37] Huang, Y.C. and Lin, Y.L. (2014) A Study on the Structure and Precipitation of Morakot (2009) Induced by the Central Mountain Range of Taiwan. Meteorology and Atmospheric Physics, 123, 115-141. https://doi.org/10.1007/s00703-013-0290-4

[38] Yunying, L.I., Wei, H. and Zhao, J. (2007) Roles of Mesoscale Terrain and Latent Heat Release in Typhoon Precipitation: A Numerical Case Study. Advances in Atmospheric Sciences, 24, 35-43. https://doi.org/10.1007/s00376-007-0035-8

[39] Fan, A.F., Lou, X.F. and Peng, X.Y. (2014) Impact of Typhoon "Damery" on Typhoon "Saola". Marine Forecasts, 31, 26-34. (In Chinese)

[40] Alpers, W., Chen, J.P., Lin, I.I. and Lien, C. (2007) Atmospheric Fronts along the East Coast of Taiwan Studied by ERS Synthetic Aperture Radar Images. Journal of the Atmospheric Sciences, 64, 922-937. https://doi.org/10.1175/JAS3863.1

[41] Huffman, G.J., Adler, R., Bolvin, D. and Nelkin, E. (2010) The TRMM Multi-Satellite Precipitation Analysis (TMPA). In: Gebremichael, M. and Hossain, F., Eds., Satellite Rainfall Applications for Surface Hydrology, Springer, 3-22. https://doi.org/10.1007/978-90-481-2915-7_1 
Submit or recommend next manuscript to OALib Journal and we will provide best service for you:

- Publication frequency: Monthly

- 9 subject areas of science, technology and medicine

- Fair and rigorous peer-review system

- Fast publication process

- Article promotion in various social networking sites (LinkedIn, Facebook, Twitter, etc.)

- Maximum dissemination of your research work

Submit Your Paper Online: Click Here to Submit

Or Contact service@oalib.com 